\title{
CONGRATULATIONS TO \\ VALERII VIKTOROVICH MIKHEEV
}

Candidate of Technical Sciences, honorable builder of the Russian Federation, and recipient of the prize awarded by the Council of Ministers of the USSR

\section{ON YOUR 80th BIRTHDAY}

Having graduated with distinction from the Moscow Civil-Engineering Institute directed by the Executive Committee of the Moscow City Soviet of Workers' Deputies in 1952, Mr. Mikheev was first employed by the Moscow Institute for the Planning of Housing and Civil Engineering Construction in the City of Moscow, and then by the Scientific-Research Institute of Foundations and Underground Structures.

After defending his candidate's dissertation, Mr. Mikheev was a senior scientific coworker from 1958 through 1963, head of the laboratory for investigation of soil properties from 1963 through 1972, and assistant director of the Scientific-Research Institute of Foundations and Underground Structures from 1972 through 1979. From 1980 through 1987, he worked as assistant to the chief of the Main Administration of Scientific Institutions, Museums, and Science and Art Establishments overseen by the State Committee of the Council of Ministers of the USSR for Construction, defining scientific policy for the construction field in the Soviet Union.

After reorganization of the State Committee of the Council of Ministers of the USSR for Construction, Mr. Mikheev returned to scientific work at the Scientific-Research Institute of Foundations and Underground Structures as head of the soil-mechanics laboratory. Since 1993, he has served as chief specialist of the Institute's experimental-analytical division.

Throughout his creative life, Mr. Mikheev has occupied himself with the development of methods of analyzing the beds of buildings and structures with respect to limiting state, as well as methods used in the investigation of soil properties. He has proposed a novel approach to the analysis of foundation beds - on the basis of reliability theory. Results of his studies have been evaluated with respect to reliability, and have been embodied in a whole series of regulatory documents published by the State Committee of the Council of Ministers of the USSR for Construction. Mr. Mikheev has been a contributing author to all of the latest Construction Rules and regulations.

He has published more than 120 scientific works, including his authoring of the first Design Manual on beds of foundations and structures for Construction Rules and Regulation II-B.1-62, and coauthoring of the familiar monograph "Reliability of beds and structures."

Mr. Mikheev has trained a plethora of young scientists, and under his tutorship, upwards of tens of aspirants and coworkers have defended their dissertations.

He has always been, and is currently found in the path of new scientific developments, whether they involve theoretical problems of soil mechanics, preparation of regulatory documents, or investigation of the properties of soils, including lunar soils. He assumed an active role in the practical design and construction of projects within the Soviet Union. In recent years, he has stepped forward as a competent and authoritative expert in the evaluation of designs for construction projects, including projects in Moscow, and is participating in the development of Moscow City Building Code "Beds, foundations, and underground structures," and a number of recommendations regarding the design and installation of foundation beds for buildings.

For his success in the national economy Mr. Mikheev has been awarded the order of "Badge of Honor," medals for the Exhibition of USSR National Economy Achievements, and a badge "For meritorious service in standardization."

Valerii Victorovich has been one of the most active authors, exacting critics, and members of the editorial staff of our journal since the moment of its inception.

The editorial office, editorial staff, and RSSMGFE extend hearty congratulations to Valerii Victorovich on his jubilee, and wish him health, vitality, and many years of creative active life.

Translated from Osnovaniya, Fundamenty i Mekhanika Gruntov, No. 3, p. 21, May-June, 2009. 